\title{
Cell growth regulation through apoptosis by activin in human gastric cancer SNU-16 cell lines
}

\author{
YOUNG IL KIM ${ }^{1}$, BYUNG-HO KIM ${ }^{2}$, INKOO KHANG ${ }^{3}$, BYUNG-NAM CHO ${ }^{4}$ and $\mathrm{HA} \mathrm{KYU} \mathrm{LEE}^{4}$ \\ ${ }^{1}$ East-West Medical Research Institute, Kyung Hee University; ${ }^{2}$ Department of Internal Medicine, Kyung Hee \\ University College of Medicine, Seoul 130-702; ${ }^{3}$ Biomedical Research Institute, Daehan Biolink Co. Ltd., \\ Chungbuk 369-831; ${ }^{4}$ Department of Life Sciences, The Catholic University of Korea, Bucheon 420-743, Korea
}

Received July 9, 2008; Accepted October 27, 2008

DOI: 10.3892/or_00000249

\begin{abstract}
Activin has a wide variety of biological functions, including the regulation of cell proliferation and inhibition of tumor cells. We have studied whether activin regulates apoptosis by investigating the effects of activin A on cell proliferation, cell cycle, apoptosis, apoptosis-related gene expression, and caspase activity in SNU-16 cells. Activin A significantly inhibited DNA synthesis and growth suppression in a time-dependent manner in SNU-16 cells. Apoptosis fraction was increased at cell cycle with an accompanying DNA fragmentation. Activin A resulted in a significant timedependent decrease in $\mathrm{Bcl}-2$ mRNA levels and increase in caspase-3 mRNA levels in SNU-16 cells. No significant difference was observed in Bax mRNA levels. Exposure of cells to activin A induced caspase-3, -8 and -9 activation in SNU-16 cells. Furthermore, co-treatment of activin with the pan-caspase inhibitor Z-VAD-FMK, caspase-3 inhibitor ZDEVE-FMK, caspase-8 inhibitor Z-IETD-FMK, and caspase9-inhibitor Z-LEHD-FMK blocked apoptosis of SNU-16 cells. Taken together, our results revealed that activin inhibits the growth of SNU-16 cells by inducing apoptosis through caspase activation.
\end{abstract}

\section{Introduction}

Activin, a member of the transforming growth factor- $\beta$ (TGF-B) superfamily has been implicated in the regulation of cellular growth and differentiation. Activins are either heterodimers or homodimers of inhibin $\beta$ subunits ( $B A \beta A$, $\beta B \beta B$ and $\beta A \beta B)(1-3)$.

Correspondence to: Dr Ha Kyu Lee, Department of Life Sciences, The Catholic University of Korea, 43-1 Yokkok 2-dong, Wonmi-gu, Bucheon 420-743, Korea

E-mail: 1hk52012@catholic.ac.kr

Key words: activin A, apoptosis, Bax, Bcl-2, caspase activity, caspase inhibitor, cell cycle, cell proliferation, human gastric cancer cell lines
Apoptosis is a form of programmed cell death that is characterized by specific morphological and biochemical properties (4). It has been demonstrated that activin A inhibits cell growth and induces apoptosis in many cell lines, including mouse B cell leukemia, androgen-dependent prostate cancer cells, mouse B cell hybridoma, hepatoma HepG2 cells, and immortalized ovarian surface epithelium (IOSE-29) cell lines (5-9). Activin-induced arrest of cellular growth is accompanied by the altered expression and the resultant altered activities of cell cycle nuclear factors. For instance, activin A causes cells to arrest in G1 phase before the appearance of apoptotic cells in mouse B cell hybridoma $(10,11)$.

Caspases are a family of highly specific proteases that play key roles during the apoptotic cell death. Caspases, constitutively expressed as inactive zymogens, are activated in a proteolytic cascade, in which initiator caspases, such as caspase- 8 and -9 , are activated by autoproteolysis in response to apoptotic cell stimulation. Initiator caspases then proteolytically activate downstream executioner caspases, such as caspase-3, which target a restricted set of structural and signaling proteins. Cleavage of these substrates accounts for cell death, as well as the phenotypic alterations characteristic of apoptosis (12). Caspase-3 is the major apoptotic executioner protease and directly cleaves most of the proteins that are proteolyzed during apoptosis $(13,14)$. Caspase activation can be mediated by intrinsic factors such as Bcl-2 on the mitochondrial membrane. Bcl-2 is normally found associated with Apaf-1. Damage causes Bcl-2 to disassociate from Apaf-1 leading to the release of cytochome $\mathrm{c}$ into the cytosol. Overexpression of Bcl-2 suppresses activin-mediated apoptosis in B-cell hybridoma (15). Therefore, activin-induced apoptosis in B cell hybridoma may be mediated through the suppression of Bcl-2 activity. The overexpression of Bcl-2 has been shown to inhibit the activation of cytoplasmic caspases after apoptotic stimuli in several cell system (16-19). Previous studies have shown that inhibition of cell growth by activin is regulated by the activin signaling pathway and the $\mathrm{p} 21^{\mathrm{CIP} 1 / \mathrm{WAF} 1}$ activation in human gastric cancer SNU-16 cell lines (20). Activin-induced apoptosis has not been reported in human gastric cancer cells.

In the present study, we demonstrate that activin leads to the growth inhibition of human gastric cancer SNU-16 cell lines by inducing an apoptosis through the caspase activation. 


\section{Materials and methods}

Cell culture and reagents. Human gastric cancer SNU-16 cell lines were supplied from the Korean Cell Line Bank and were cultured in RPMI-1640 medium (Gibco, Grand Island, NY, USA) containing 10\% fetal bovine serum (FBS), $100 \mathrm{U} / \mathrm{ml}$ penicillin and $100 \mu \mathrm{g} / \mathrm{ml}$ streptomycin. Cells were incubated at $37^{\circ} \mathrm{C}$ in a humidified atmosphere of $5 \% \mathrm{CO}_{2}$ in 95\% air. The recombinant human activin $\mathrm{A}$ (activin $\mathrm{A}$ ) was purchased from R \& D systems (R\&D Systems, Minneapolis, MN, USA).

DNA synthesis assay. For the $\left[{ }^{3} \mathrm{H}\right]$ thymidine incorporation assay, cells were plated at a density of $5 \times 10^{3}$ cells/well in 96-well plates and incubated with $100 \mathrm{ng} / \mathrm{ml}$ of activin A for 24,48 and $72 \mathrm{~h}$, respectively. During the last $6 \mathrm{~h}$ of incubation, $0.5 \mu \mathrm{Ci}$ of $\left[{ }^{3} \mathrm{H}\right]$ thymidine was added to each well. Cells were harvested on a cell harverster onto a glass filter and mixed with Aqualuma Plus solution (Lumac-LSC, Groningen, The Netherlands). The incorporation of radioactivity was determined with a $B$-liquid scintillation counter (LS 3000 , Beckman Coulter, Fullerton, CA, USA).

Determination of cell doubling time. Cells $\left(5 \times 10^{4}\right.$ cells $\left./ \mathrm{ml}\right)$ were treated with $100 \mathrm{ng} / \mathrm{ml}$ of activin A and cultured for 5 days and then changed with fresh medium and drug every 2 days. Untreated cells were analyzed under similar conditions as a control. Cell number was counted by the trypan blue exclusion method each day for 5 consecutive days using hemocytometer. The average cell number from two plates was determined, and the mean cell numbers were plotted to define the cell population doubling times. The cell population doubling time was calibrated by a formula of Kuchler (21).

Cell cycle analysis. Cells were plated at a density of $5 \times 10^{4}$ cells $/ \mathrm{ml}$ in 6-well plates and incubated with $100 \mathrm{ng} / \mathrm{ml}$ of activin A for 24,48 and $72 \mathrm{~h}$, respectively. After incubation, the cells were harvested and washed with PBS. Cell pellets were resuspended in $1 \mathrm{ml}$ of hypotonic solution (3.4 mM sodium citrate, $1 \mathrm{mM}$ Tris, $0.1 \mathrm{mM}$ EDTA, $0.1 \%$ Triton $\mathrm{X}-100)$, stained with propidium iodide $(50 \mu \mathrm{g} / \mathrm{ml})$, and analyzed by a FACScan (Becton Dickinson Immunocytometry System, San Jose, CA, USA).

Analysis of DNA fragmentation. Cells were treated with $100 \mathrm{ng} / \mathrm{ml}$ of activin A for 24, 48 and $72 \mathrm{~h}$, respectively. After treatment, the cells were washed twice with PBS and incubated with $500 \mu 1$ of DNA lysis buffer [10 mM Tris (pH 7.4), $5 \mathrm{mM}$ $\mathrm{Na}_{2}$ EDTA, $1 \%$ Triton $\mathrm{X}-100$ ] for $20 \mathrm{~min}$ on ice and then centrifuged at $14000 \mathrm{x}$ g for $20 \mathrm{~min}$ at $4^{\circ} \mathrm{C}$. The supernatants containing fragmented DNA was digested with $20 \mu \mathrm{g} / \mathrm{ml}$ of RNase A for $1 \mathrm{~h}$ at $37^{\circ} \mathrm{C}$ and incubated for overnight with $100 \mu \mathrm{g} / \mathrm{ml}$ of proteinase $\mathrm{K}$. The DNA was extracted by phenol/chloroform, precipitated in 2 volume ethanol, and centrifuged at $14000 \mathrm{xg}$ for $15 \mathrm{~min}$ at $4^{\circ} \mathrm{C}$. The DNA was dissolved in $10 \mu 1 \mathrm{TE}$ buffer, and the entire DNA sample was electrophoresed in a $1.5 \%$ agarose gel containing $0.5 \mu \mathrm{g} / \mathrm{ml}$ ethidium bromide and visualized by image analysis (Gel Doc 1000 gel document system, Bio-Rad, Hercules, CA, USA).
RNA extraction and RT-PCR procedures. Total RNA was purified from cultured cells using the RNA-Bee solution kit following the manufacturer's protocol (Tel-test, Friendswood, TX, USA). First-strand cDNA synthesis was then made on $1 \mu \mathrm{g}$ of RNA using a reverse transcriptase system (Promega, Madison, WI, USA). Reverse transcription was primed using random hexamers. The polymerase chain reaction (PCR) was performed with $2 \mu \mathrm{l}$ of cDNA in a $50 \mu 1$ reaction mixture of 1X PCR buffer, $200 \mu \mathrm{M}$ of each dNTP, 20 pmol each primer, and 1 Units of AmpliTaq Gold DNA polymerase (Roche, Applied Biosystems, Foster City, CA, USA). Primer sequences are shown in Table I. The condition for amplification were as follows: first denaturation at $95^{\circ} \mathrm{C}$ for $14 \mathrm{~min}$, then denaturation at $95^{\circ} \mathrm{C}$ for $1 \mathrm{~min}$, annealing at $55-65^{\circ} \mathrm{C}$ for $1 \mathrm{~min}$, and extension at $72^{\circ} \mathrm{C}$ for $1 \mathrm{~min}$ for 22-30 cycles and final extension at $72^{\circ} \mathrm{C}$ for $7 \mathrm{~min}$. PCR product $(10 \mu 1)$ was separated by electrophoresis on a $2 \%$ agarose gel containing ethidium bromide and visualized by image analysis. The results were shown as the ratio of relative absorbance of Bcl-2, Bax and caspase-3/ß-actin detected by densitometry.

Detection of apoptosis. For the determination of apoptosis in SNU-16 cells, the quantification of apoptotic cells was measured using the cell death detection ELISA ${ }^{\text {plus }}$ kit (Roche Molecular Biochemicals, Mannheim, Germany). Cells were plated at a density of $5 \times 10^{4}$ cells $/ \mathrm{ml}$ in 6 -well plates and incubated with $100 \mathrm{ng} / \mathrm{ml}$ of activin A for 24,48 and $72 \mathrm{~h}$, respectively. After incubation, the cells were harvested and lysed with $0.1 \mathrm{ml}\left(1 \times 10^{4}\right.$ cells $)$ lysis buffer. Apoptotic cells in cell lysates were assayed for DNA fragments according to the manufacturer's protocol. Cell lysate $(20 \mu 1)$ was used for the cell death ELISA. DNA fragmentation was measured at $405 \mathrm{~nm}$ against an untreated control.

For the assessment of cytosolic histone-bound DNA fragments, cell death detection ELISA plus kit was used. Briefly, SNU-16 cells were incubated in the presence of $100 \mathrm{ng} / \mathrm{ml}$ of activin A with or without a pan-caspase inhibitor, Z-VAD-FMK, or a caspase-3-specific inhibitor, Z-DEVD-FMK, caspase-8-specific inhibitor, Z-IETD-FMK, and caspase-9-specific inhibitor, Z-LEHD-FMK (R\&D Systems) for $72 \mathrm{~h}$. Cells were lyzed and the lyzate was added to streptavidin-coated 96-well plates. Also a mixture of biotinylated antihistone and peroxidase-coupled anti-DNA antibodies was added. Following a $2 \mathrm{~h}$ incubation and washing, the amount of cytoplasmic nucleosome was quantified by determining the peroxidase retained in the immunocomplex. The peroxidase activity was determined spectrophotometrically with 2,2'-azino-di[3-ethylbenzothiazoline-sulfonate] (ABTS) as a substrate at the absorbance of $405 \mathrm{~nm}$.

Measurement of caspase protease activity. To measure the enzymatic activity of caspase proteases, caspase colorimetric protease assay sampler kit (BioSource, Camarillo, CA, USA) was used. SNU-16 cells $\left(2 \times 10^{6}\right.$ cells $)$ were treated with $100 \mathrm{ng} / \mathrm{ml}$ of activin A for 24,48 and $72 \mathrm{~h}$, respectively. Cells were harvested and cell pellets were lysed in $50 \mu \mathrm{l}$ of lysis buffer on ice for $10 \mathrm{~min}$. The supernatant (cytosol extract) were measured by BCA protein assay. The activities of 
Table I. Oligonucleotide sequences of PCR primers.

\begin{tabular}{llcc}
\hline Oligo & \multicolumn{1}{c}{ Sequences } & $\begin{array}{c}\text { Annaling } \\
\text { temperature }\left({ }^{\circ} \mathrm{C}\right)\end{array}$ & Cycles \\
\hline Bcl-2 & 5'-CTTTGAGTTCGGTGGGGTCATGTG-3' & 58 & 30 \\
& 5'-TGACTTCACTTGTGGCCCAGATAGG-3' & & 275 \\
Bax & 5'-ATGGACGGGTCCGGGGAGCAGC-3' & 65 & 30 \\
& 5'-CCCCAGTTGAAGTTGCCGTCAG-3' & & 28 \\
Caspase-3 & 5'-CTCGGTCTGGTACAGATGTCGATG-3' & 60 & 22 \\
3-actin & 5'-GGTTAACCCGGGTAAGAATGTGCA-3' & 534 \\
& 5'-TCATGAGGTAGTCAGTCAGG-3' & 53 & 305 \\
\hline
\end{tabular}

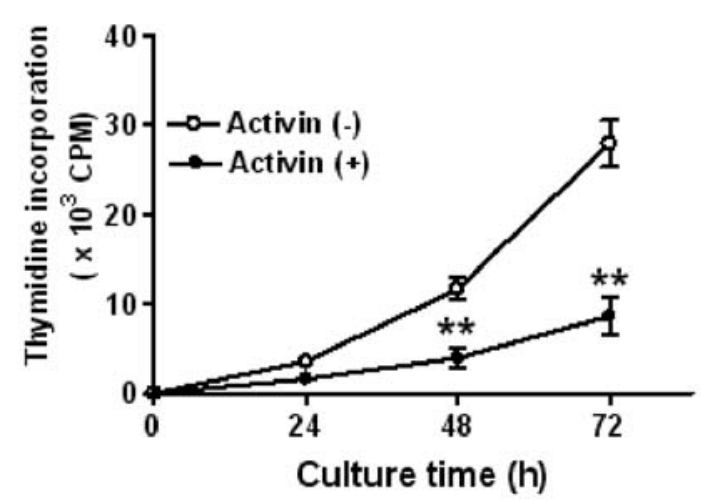

Figure 1. Effects of activin A on DNA synthesis in SNU-16 cells. Cells were cultured with activin A $(100 \mathrm{ng} / \mathrm{ml})$ for 24,48 and $72 \mathrm{~h}$. The proliferative index was determined by a $\left[{ }^{3} \mathrm{H}\right]$ thymidine incorporation assay. Values are the mean \pm SD of three independent experiments. ${ }^{*} \mathrm{P}<0.05$ and ${ }^{* *} \mathrm{P}<0.01$ compared to control.

caspase-3-, -8 and -9-like proteases were measured by proteolytic cleavage of substrates including DEVD-pNA (caspase-3 substrate), IETD-pNA (caspase-8 substrate), and LEHD- $p$ NA (caspase-9 substrate) respectively. These colorimetry substrates were solubilized in an assay buffer. After incubated at $37^{\circ} \mathrm{C}$ for $1 \mathrm{~h}$ in the dark, colorimetric from the lysates was measured with a microplate reader at $405 \mathrm{~nm}$. Caspase-3, -8 and -9 activities were determined by direct comparison to the level of the uninduced control.

Statistical analysis. Values are expressed as the mean \pm SD. Student's t-test was used to evaluate differences between the control samples and activin A-treated samples. Inhibition of apoptosis was estimated by the differences between the activin A-treated sample and caspase inhibitor-treated sample with activin $\mathrm{A} .{ }^{*} \mathrm{P}<0.05$ and ${ }^{* *} \mathrm{P}<0.01$ were considered statistically significant.

\section{Results}

Effects of activin A on the DNA synthesis. The proliferative indexes of SNU-16 cells treated with $100 \mathrm{ng} / \mathrm{ml}$ of activin A
Table II. Effects of activin A on growth suppression.

\begin{tabular}{|c|c|c|c|}
\hline \multirow[b]{2}{*}{ Cell lines } & \multicolumn{2}{|c|}{ Doubling time } & \multirow{2}{*}{$\begin{array}{l}\text { Fold growth } \\
\text { suppression }\end{array}$} \\
\hline & $\operatorname{activin}(-)$ & $\operatorname{activin}(+)$ & \\
\hline SNU-16 & 34.2 & 47.3 & 1.38 \\
\hline
\end{tabular}

for 24,48 and $72 \mathrm{~h}$, respectively. DNA synthesis was determined by a thymidine incorporation assay (Fig. 1). The SNU-16 cell proliferation was decreased significantly by activin A treatment in a time-dependent manner.

Effects of activin A on growth suppression. The cell population doubling times (PDT) was measured by a cell counter in SNU-16 cells after activin A treatment to determine whether cell growth was suppressed (Table II). Cells were cultured under the activin A for 5 consecutive days and the doubling time was increased in activin A treated SNU-16 1.38-fold compared to control.

Effects of activin A on the cell population. To examine the effect of activin on cell cycle progression, SNU-16 cells were treated with $100 \mathrm{ng} / \mathrm{ml}$ of activin A for 24, 48 and $72 \mathrm{~h}$ respectively, and flow cytometric analyses were performed (Fig. 2). In SNU-16 cells, the apoptosis fraction was increased 15,34 and $71 \%$ whereas the $\mathrm{G} 2 / \mathrm{M}$ fraction was decreased 20,12 and $6 \%$, respectively, at the indicated culture time after activin A treatment.

Effects of activin A on the apoptosis. To examine the role of activin in the induction of apoptosis, SNU-16 cells were treated with $100 \mathrm{ng} / \mathrm{ml}$ of activin A for 24, 48 and $72 \mathrm{~h}$, respectively. Then DNA fragmentation as a sign of apoptosis was confirmed by fragmented band detection after agarose gel electrophoresis (Fig. 3A). A ladder of fragmented DNA was detected $48 \mathrm{~h}$ after incubation and increased until $72 \mathrm{~h}$ in activin A treated SNU-16 cells. Using a cell death detection ELISA, we reconfirmed the apoptosis of SNU-16 cells after activin A treatment, resulting in a similar increase pattern of apoptosis as described in Fig. 3A and B. 

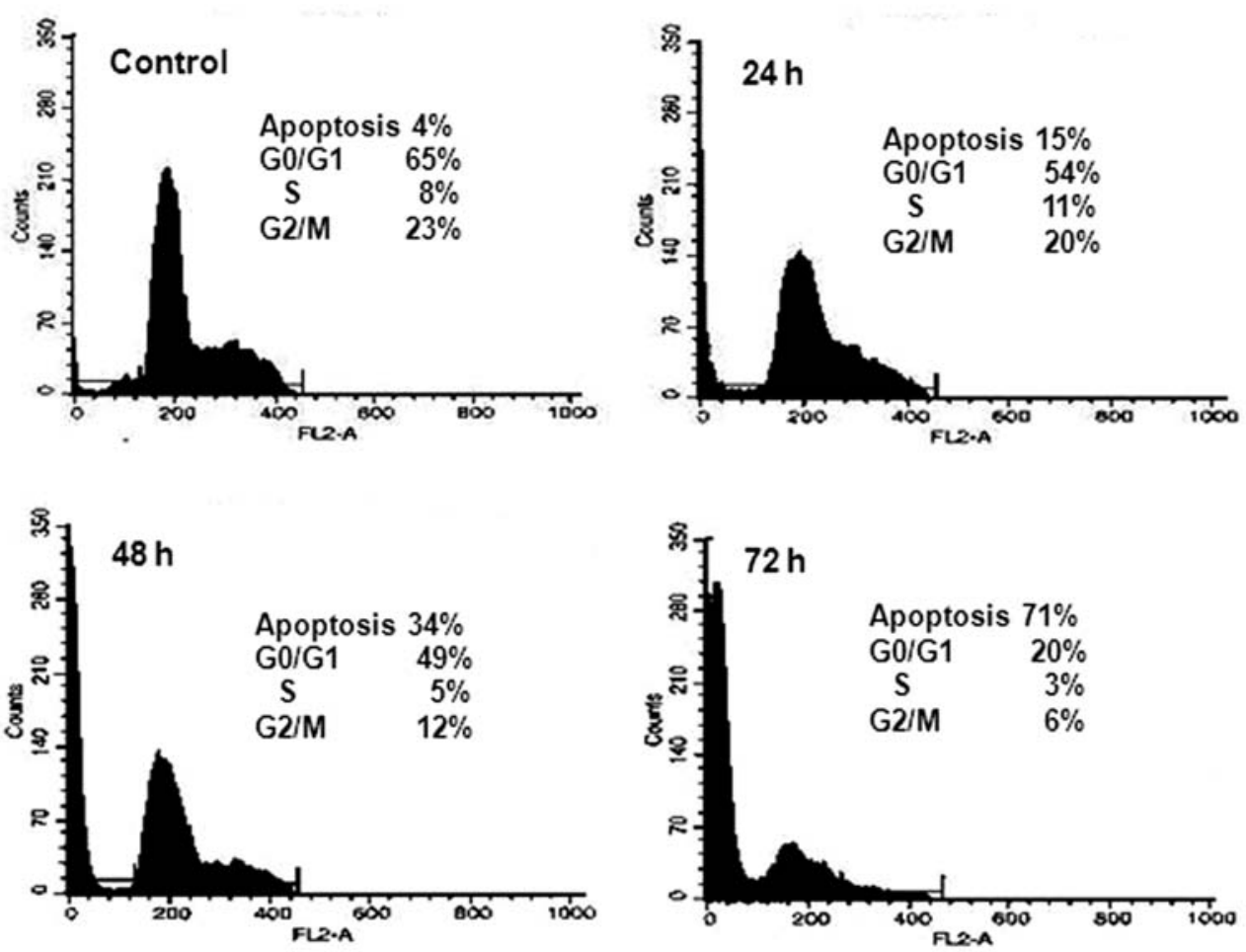

Figure 2. Cell cycle analysis by FACScan of SNU-16 cells treated with activin A. Cells were cultured with activin A (100 ng/ml) as described in Fig. 1. Cells were harvested and stained with propidium iodide. The DNA content was analyzed by flow cytometry. The percentage of cells in apoptosis, G0/G1, S, and G2/M phases was calculated.

A

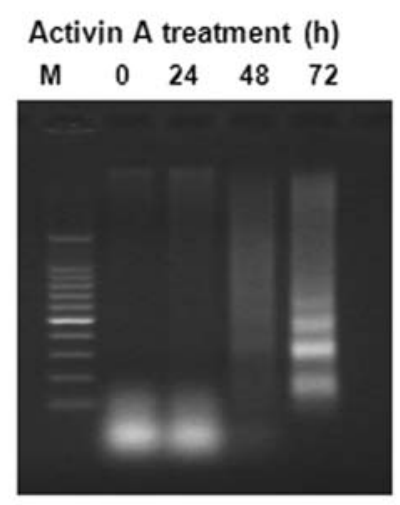

B

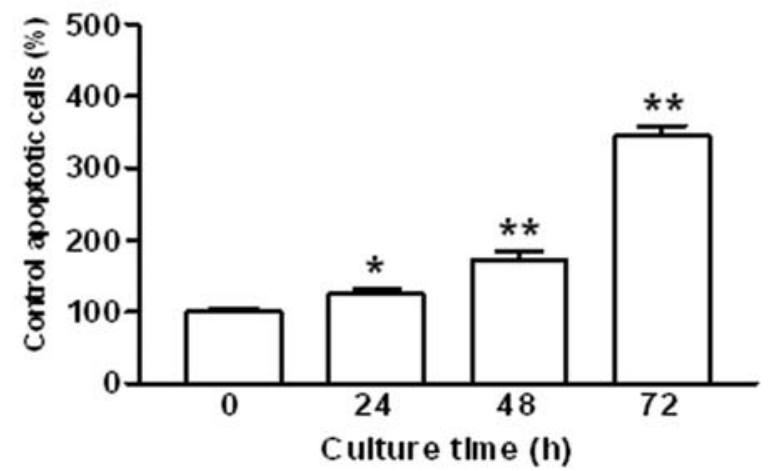

Figure 3. Effects of activin A on the induction of apoptosis in SNU-16 cells. Cells were cultured with activin A (100 ng/ml) as described in Fig. 1. (A) DNA fragmentation was extracted from genomic DNA and resolved on $1.5 \%$ agarose gel by electrophoresis. (B) Apoptotic cells were measured using a cell death detection ELISA. Values are the mean $\pm \mathrm{SD}$ of three independent experiments. ${ }^{*} \mathrm{P}<0.05$ and ${ }^{* *} \mathrm{P}<0.01$ compared to control.

Effects of activin $A$ on the expression of Bcl-2, Bax, and caspase-3 mRNA. The level of Bcl-2, Bax, and caspase-3 mRNAs were examined by RT-PCR (Fig. 4). SNU-16 cells were treated with $100 \mathrm{ng} / \mathrm{ml}$ of activin A for 24,48 and $72 \mathrm{~h}$, respectively. The level of Bcl-2 was decreased whereas that of caspase-3 was increased in a time-dependent manner. No significant difference was observed in the level of Bax mRNA in SNU-16 cells.

Involvement of caspases in activin A-induced apoptosis. Caspases are cysteine-aspartate proteases that play critical roles during the initiation and execution of apoptosis. To further elucidate the mechanism involved in the observed apoptosis, intracellular caspase-3, -8 and -9 activities were measured in SNU-16 cells at various time points (Fig. 5). In SNU-16 cells, caspase-3 activity increased as early as $24 \mathrm{~h}$ after treatment and reached a maximal level at $72 \mathrm{~h}$, which was 3.0-fold greater than that of control. Caspase- 8 and -9 activities in SNU-16 cells increased 1.8 and 1.7-fold at $72 \mathrm{~h}$ respectively, compared to unstimulated cells. To confirm whether or not the activation of caspases is involved in activin A-induced apoptosis, apoptosis of SNU-16 cells by 

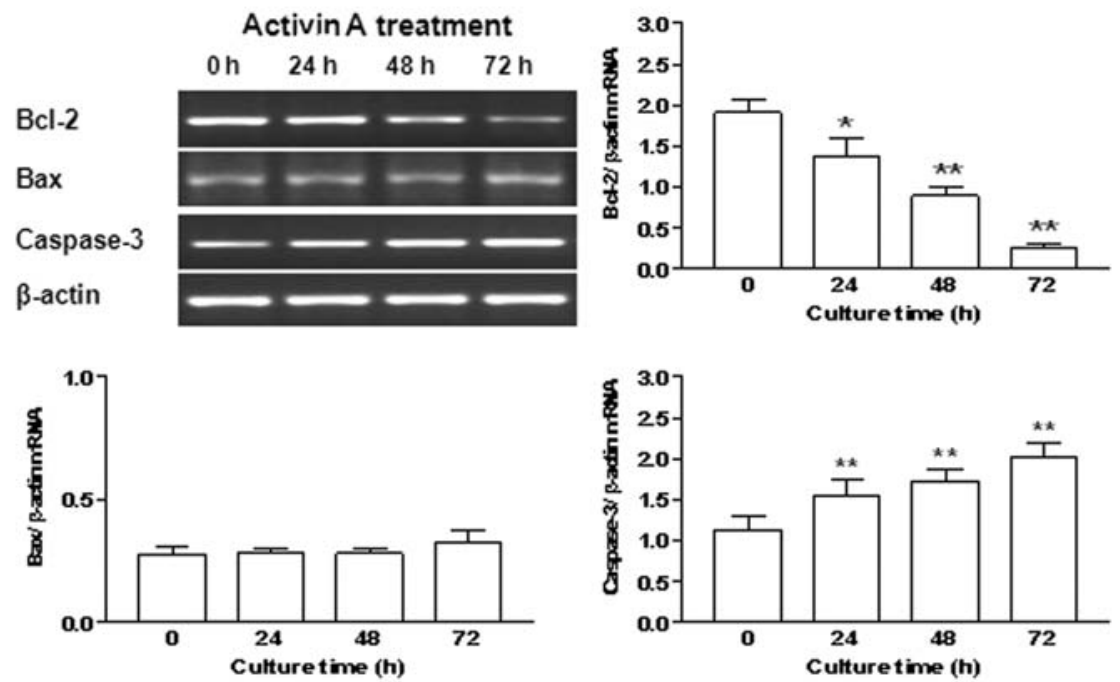

Figure 4. Effects of activin A on Bcl-2, Bax, and caspase-3 mRNA expression in SNU-16 cells. Cells were cultured with activin A (100 ng/ml) as described in Fig. 1 and mRNA levels were measured by RT-PCR. Values are mean \pm SD of three independent experiments, and reported as the ratio of Bcl-2, Bax, and caspase-3 to $ß$-actin signals. ${ }^{*} \mathrm{P}<0.05$ and ${ }^{* *} \mathrm{P}<0.01$ compared to control.

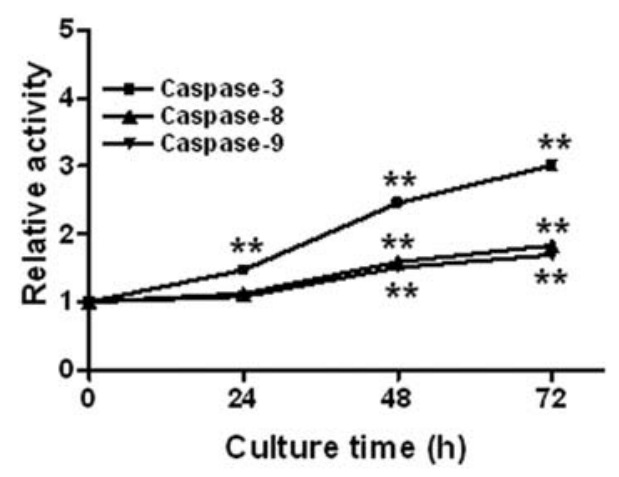

Figure 5. Caspase activation induced by activin A. Cells were cultured with activin A (100 ng/ml) as described in Fig. 1. The enzymatic activity of caspase proteases was measured by caspase colorimetric assay. Control cells were assigned a value of 1 and other values were expressed relative to these and were plotted against the time after activin A treatment. Values are the mean $\pm \mathrm{SD}$ of three independent experiments. ${ }^{*} \mathrm{P}<0.05$ and ${ }^{* *} \mathrm{P}<0.01$ compared to control. activin A was determined by ELISA in the presence of a pan-caspase inhibitor, Z-VAD-FMK, a caspase-3-specific inhibitor, Z-DEVD-FMK, a caspase-8-specific inhibitor, ZIETD-FMK, and a caspase-9-specific inhibitor, Z-LEHDFMK. As shown in Fig. 6, apoptosis of SNU-16 cells by $100 \mathrm{ng} / \mathrm{ml}$ of activin A was inhibited by 10-50 $\mu \mathrm{M}$ Z-VADFMK, 10-50 $\mu \mathrm{M}$ Z-DEVD-FMK, 10-50 $\mu \mathrm{M}$ Z-IETD-FMK, and 10-50 $\mu \mathrm{M}$ Z-LEHD-FMK respectively. At $50 \mu \mathrm{M}$, the effect of Z-DEVD-FMK was greater than other inhibitors on the apoptosis of SNU-16 cells.

\section{Discussion}

Activins are known to be involved in many cellular events, such as cell proliferation, differentiation, and apoptosis. In previous studies, ten human gastric cancer cell lines showed cell proliferation after activin treatment. Inhibition of cell growth by activin observed only SNU-16 cell lines and altered the expression of the activin receptor and Smad

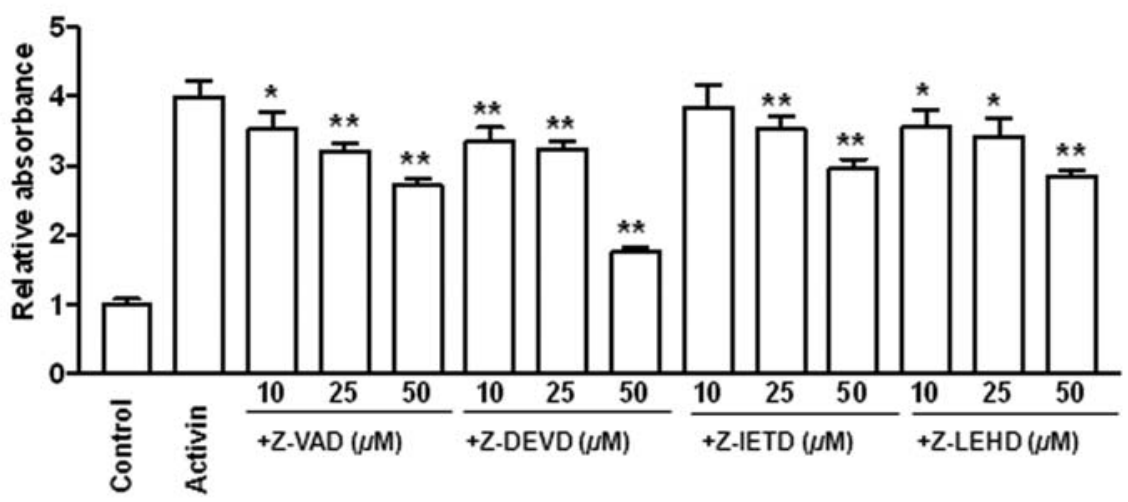

Figure 6. Effects of caspase inhibitors on activin A-induced apoptosis. SNU-16 cells were treated with activin A (100 ng/ml) in presence or absence of each Z-VAD-FMK (10-50 $\mu \mathrm{M})$, Z-DEVD-FMK (10-50 $\mu \mathrm{M})$, Z-IETD-FMK (10-50 $\mu \mathrm{M})$, and Z-LEHD-FMK (10-50 $\mu \mathrm{M})$ for $72 \mathrm{~h}$. Then, the cells were measured using a cell death detection ELISA. Values are the mean \pm SD of three independent experiments. ${ }^{*} \mathrm{P}<0.05$ and ${ }^{* *} \mathrm{P}<0.01$ compared to activin-treated cells vs. caspase inhibitor-treated cells with activin. 
mRNA. However, activin is regulated the activin signaling pathway and activated the $\mathrm{p} 21^{\mathrm{CIP} 1 / \mathrm{WAF} 1}$ in human gastric cancer SNU-16 cell lines (20). Activin has been found to significantly inhibit cell proliferation within $24 \mathrm{~h}$ at concentrations of $5 \mathrm{ng} / \mathrm{ml}$ or $50 \mathrm{ng} / \mathrm{ml}$ activin in prostate LNCaP cells. This growth inhibition was more pronounced at $48 \mathrm{~h}$, with even the lowest dose studied $(0.5 \mathrm{ng} / \mathrm{ml})$ inhibiting cell proliferation (22). In HepG2 hepatoma cells, activin $(300 \mathrm{U} / \mathrm{ml})$ resulted in cell growth inhibition, with decreased in thymidine incorporation and cell numbers, which started at $24 \mathrm{~h}$ and continued for 5 days (23). In the present study, treatment with activin A $(100 \mathrm{ng} / \mathrm{ml})$ also significantly decreased the DNA synthesis of SNU-16 cells in a timedependent manner. Activin leads to a substantial increase in doubling times of SNU-16 cells. Taken together, these results suggest that activin may act as a growth inhibitor that prevents inappropriate proliferation of SNU-16 cells.

Activin causes cell cycle arrest in G1 phase. In mouse B cell hybridoma, activin-sensitive cells increased the population of nuclei with reduced DNA content, representing apoptotic nuclei (15). On the other hand, previous reports have demonstrated that activin induced apoptosis in androgendependent prostate cancer cells and hepatoma $(6,8)$. Activin A mediates growth inhibition and cell cycle arrest through Smads in human breast cancer cells (24). In the present study, activin treatment increased the apoptosis fraction at cell cycle in SNU-16 cells in a time-dependent manner. Treatment with activin A $(100 \mathrm{ng} / \mathrm{ml})$ resulted in an increase in DNA fragmentation and apoptotic cells of SNU-16 cells. These results suggest that activin not only inhibits SNU-16 cell growth and blocks cell cycle progression at the G1 phase, but also induces apoptosis.

The Bcl-2 gene family members have been widely considered to be regulators of cell death $(25,26)$. Among proand anti-apoptotic genes, $\mathrm{Bax}$ and $\mathrm{Bcl}-2$ are dominant regulators of apoptosis in that the ratio of $\mathrm{Bcl}-2$ to $\mathrm{Bax}$ is important in determining susceptibility to apoptosis (25). Activin-induced apoptosis in B cell hybridoma cells may be mediated through the suppression of Bcl-2 activity, whereas activin up-regulated Bcl-X expression (27). The up-regulation of Bcl-2 in these cells suppressed activin-mediated apoptosis. Overexpression of the anti-apoptotic factor Bcl-2 suppressed activin-mediated apoptosis in B cell hybridoma, and the expression of the pro-apoptotic Bax were unchanged, after activin treatment (15). The expression level of Bcl-2 mRNA is higher in IOSE-29EC cells than in IOSE-29 cells, whereas no difference was observed in the expression levels of Bax mRNA between IOSE-29 and IOSE-29EC cells (9). In SNU16 cells, Bcl- 2 mRNA levels decreased in a time-dependent manner after activin stimulation, and caspase- 3 mRNA levels were increased. No difference was observed between Bax mRNA levels in SNU-16 cells. These results suggest that both the decrease of Bcl-2 expression and the increase of caspase- 3 expression mediate the apoptotic activation of activin.

Many genes are involved in the progression of apoptosis. Activin not only regulates cell growth and differentiation, but it also induces programmed cell death in several types of cells. It appear that activin induces apoptosis by activating caspases, the proteases responsible for cell death (28). To investigate the molecular mechanism underlying apoptosis of human gastric cancer cells, we assessed the status of several members of the caspase family, the key molecules of apoptosis, during activin-mediated apoptosis of SNU-16 cells. We found that treatment of SNU-16 cells with activin produced increases in intracellular caspase-3, -8 and -9 activities. This finding was confirmed by experiments using the pan-caspase inhibitor Z-VAD-FMK, the caspase-3specific inhibitor Z-DEVD-FMK, the caspase-8-specific inhibitor Z-IETD-FMK, and caspase-9-specific inhibitor ZLEHD-FMK, which attenuated activin-mediated apoptosis. The decrease of activities of caspase-3, -8 and -9 after $72 \mathrm{~h}$ treatment with activin seems to be due to the considerably advance in cell death. These results suggest that apoptosis of SNU-16 cells that is induced by activin is mediated by caspase activation. In SNU-16 cells, induction of apoptosis by activin occurs through mitochondrial pathway involving initiator caspase- 8 and -9 and effector caspase-3.

In conclusion, we demonstrated that activin inhibits the growth of SNU-16 cells by induction of apoptosis, which involve caspase activation. The study of the growth-inhibitory effect of activin will contribute to increased understanding of the critical signaling pathway for SNU-16 cells.

\section{Acknowledgements}

This research was supported by the Research Fund 2007 from the Catholic University of Korea.

\section{References}

1. Ying SY: Inhibins and activins: chemical properties and biological activity. Proc Soc Exp Biol Med 186: 253-264, 1987.

2. Ying SY: Inhibins, activins, and follistatins: gonadal proteins modulating the secretion of follicle-stimulating hormone. Endocr Rev 9: 267-293, 1988.

3. Robertson DM, Giacometti M, Foulds LM, Lahnstein J, Goss NH, Hearn MT and de Kretser DM: Isolation of inhibin alphasubunit precursor proteins from bovine follicular fluid. Endocrinology 125: 2141-2149, 1989.

4. Wyllie AH, Kerr JF and Currie AR: Cell death: the significance of apoptosis. Int Rev Cytol 68: 251-306, 1980.

5. Nishihara T, Okahashi N and Ueda N: Activin A induces apoptotic cell death. Biochem Biophys Res Commun 197: 985-991, 1993.

6. Wang QF, Tilly KI, Tilly JL, Preffer F, Schneyer AL, Crowley WF Jr and Sluss PM: Activin inhibits basal and androgen-stimulated proliferation and induces apoptosis in the human prostatic cancer cell line, LNCaP. Endocrinology 137: 5476-5483, 1996.

7. Hashimoto O, Yamato K, Koseki T, et al: The role of activin type I receptors in activin A-induced growth arrest and apoptosis in mouse B-cell hybridoma cells. Cell Signal 10: 743-749, 1998.

8. Chen W, Woodruff TK and Mayo KE: Activin A-induced HepG2 liver cell apoptosis: Involvement of activin receptors and Smad proteins. Endocrinology 141: 1263-1272, 2000.

9. Choi KC, Kang SK, Tai CJ, Auersperg N and Leung PC: The regulation of apoptosis by activin and transforming growth factor- $\beta$ in early neoplastic and tumorigenic ovarian surface epithelium. J Clin Endocrinol Metab 86: 2125-2135, 2001.

10. Yamato K, Koseki T, Ohguchi M, Kizaki M, Ikeda Y and Nishihara T: Activin A induction of cell-cycle arrest involves modulation of cyclin D2 and p21 $1^{\mathrm{CIP} 1 / \mathrm{WAF} 1}$ in plasmacytic cells. Mol Endocrinol 11: 1044-1052, 1997.

11. Ishisaki A, Yamato K, Nakao A, Nonaka K, Ohguchi M, ten Dijke P and Nishihara T: Smad7 is an activin-inducible inhibitor of activin-induced growth arrest and apoptosis in mouse B cells. J Biol Chem 273: 24293-24296, 1998.

12. Thornberry NA and Lazebnik Y: Caspases: enemies within. Science 281: 1312-1316, 1998. 
13. Nicholson DW: Caspase structure, proteolytic substrates, and function during apoptotic cell death. Cell Death Differ 6: 1028-1042, 1999.

14. Budihardjo I, Oliver H, Lutter M, Luo X and Wang X: Biochemical pathways of caspase activation during apoptosis. Annu Rev Cell Dev Biol 15: 269-290, 1999.

15. Koseki T, Yamato K, Krajewski S, Reed JC, Tsujimoto Y and Nishihara T: Activin A-induced apoptosis is suppressed by BCL-2. FEBS Lett 376: 247-250, 1995.

16. Armstrong RC, Aja T, Xiang J, et al: Fas-induced activation of the cell death-related protease CPP32 in inhibited by Bcl-2 and by ICE family protease inhibitors. J Biol Chem 271: 16850-16855, 1996.

17. Boulakia CA, Chen G, Ng FW, et al: Bcl-2 and adenovirus E1B $19 \mathrm{kDA}$ protein prevent E1A-induced processing of CPP32 and cleavage of poly (ADP-ribose) polymerase. Oncogene 12: 529-535, 1996

18. Chinnaiyan AM, Orth K, O'Rourke K, Duan H, Poirier GG and Dixit VM: Molecular ordering of the cell death pathway: Bcl-2 and Bcl-XL function upstream of the ced3-like apoptotic proteases. J Biol Chem 271: 4573-4576, 1996.

19. Srinivasan A, Foster LM, Testa MP, Ord T, Keane RW, Bredesen DE and Kayalar C: Bcl-2 expression in neural cells blocks activation of ICE/CED-3 family proteases during apoptosis. J Neurosci 16: 5654-5660, 1996.

20. Kim YI, Lee HJ, Khang I, Cho BN and Lee HK: Selective inhibition of cell growth by activin in SNU-16 cells. World J Gastroenterol 12: 3000-3005, 2006.
21. Kuchler RJ: Development of animal cell population in vitro. In: Biochemical Methods in Cell Culture and Virology. Kuchler RJ (ed). Dowden, Hutchinson and Ross, Inc., Stroudsburg, PA, pp90-113, 1997.

22. Dalkin AC, Gilrain JT, Bradshaw D and Myers CE: Activin inhibition of prostate cancer cell growth: Selective actions on androgen-responsive LNCaP cells. Endocrinology 137: 5230-5235, 1996.

23. Zauberman A, Oren $M$ and Zipori D: Involvement of $\mathrm{p} 21^{\mathrm{WAF} 1 / \mathrm{Cip} 1}, \mathrm{CDK} 4$ and $\mathrm{Rb}$ in activin A mediated signaling leading to hepatoma cell growth inhibition. Oncogene 15: 1705-1711, 1997.

24. Burdette JE, Jeruss JS, Kurley SJ, Lee EJ and Woodruff TK: Activin A mediates growth inhibition and cell cycle arrest through Smads in human breast cancer cells. Cancer Res 65: 7968-7975, 2005.

25. Chao DT and Korsmeyer SJ: Bcl-2 family: regulators of cell death. Annu Rev Immunol 16: 395-419, 1998.

26. Minn AJ, Swain RE, Ma A and Thompson CB: Recent progress on the regulation of apoptosis by bcl-2 family members. Adv Immunol 70: 245-279, 1998.

27. Koseki T, Yamato K, Ishisaki A, Hashimoto O, Sugino H and Nishihara T: Correlation between Bcl-X expression and B-cell hybridoma apoptosis induced by activin A. Cell Signal 10: 517-521, 1998

28. Chen YG, Lui HM, Lin SL, Lee JM and Ying SY: Regulation of cell proliferation, apoptosis, and carcinogenesis by activin. Exp Biol Med 227: 75-87, 2002. 